\title{
The efficiency of some natural alternatives in root- knot nematode control
}

\begin{abstract}
Plant extracts are, nowadays, extensive used as environment friendly ways for biological control of parasitic pests, including the root-knot nematodes, instead of using chemical pesticides. Therefore, the aim of this study was to analyze leaf and root extracts nematicidal activities of four selected medicinal plants (i.e., Azaddirachta indica, Moringaoleifera, Lantana camara, and Glycyrrhizaglabra) against the root-knot nematode; Meloidogyne spp. Roots of G. glabra and leaves of A. indica, M. oleifera, and L. camara were collected from different sites in Fayoum Governorate. Roots and leaves were air-dried, powdered and then extracted by ethanol $95 \%$ for L. camara and G. glabra or by petroleum ether for $A$. indica and $M$. oleifera. The nematode eggs were exposed to the different extracts at different concentrations (i.e., 500, 1000, 2000, 4000ppm) for 24, 48 and 72h. Results showed that all four plant extracts caused significant decreases in egg hatching, but to varying degrees. $A$. indica extract was the most effective in preventing egg hatching, followed by $M$. oleifera extract. There was a gradual decrease in egg hatching with increasing the extract concentration and the duration of exposure. As the most effective, the crude extract of $A$. indica was analyzed by using GC/MS for the effective ingredients and found to be included alkaloids, flavonoids, saponins, amides including benzamide and ketones, and others, which showed effectiveness in preventing the egg hatching of the rootknot nematode; Meloidogyne incognita.
\end{abstract}

Keywords: extract, Meloidogyne spp., egg hatchability, mortality, GC/MS
Volume 8 Issue 4 - 2018

\author{
Sanaa A Haroon,' Baraa AA Hassan,' Fatma \\ MI Hamad,' Mostafa M Rady² \\ 'Department of Plant Protection, Faculty of Agriculture, Fayoum \\ University, Egypt \\ ${ }^{2}$ Department of Botany, Faculty of Agriculture, Fayoum \\ University, Egypt
}

Correspondence: Mostafa M Rady, Department of Botany, Faculty of Agriculture, Fayoum University, 635 I4 Fayoum, Egypt Emailsmmr02@fayoum.edu.eg,mrady2050@gmail.com

Received: May 26, 2018 | Published: August 10,2018

\section{Introduction}

Nematodes are found in a wide variety of habitats. Free-living nematodes live in the soil, in freshwater, marine sands and muds. In soil, they are important components of nutrient turnover. Other nematodes are parasites of almost every species of animal, humans, plant and they cause enormous social and economic damage. ${ }^{1}$ Phytoparasitic nematodes parasitize plants to seek suitable food. This food source is basically planted cell contents. Thus a plant response to parasitism is the reaction to the cellular feeding of the nematode. ${ }^{2}$ Most phytoparasitic nematodes infect plant roots and some species have evolved sophisticated interactive relationships with host cells to sustain a sedentary parasitic habit. ${ }^{3}$ Plants carry a wide range of microorganisms in their phyllosphere and Rhizosphere which not only cause a large variety of diseases but also control of pathogens. ${ }^{4}$ Nematodes have an important niche in agro-ecosystem, causing a reduction in plant productivity and growth. Root-knot nematodes (Meloidogyne spp.) are very common and the most important nematode species of greenhouse-growing plants. Indiscriminate use of chemical nematicides to control nematode causes great injuries to human being, animal, vegetation and to the environment as a whole due to their non-target effect, hazardous nature besides they are expensive. So with the increasing awareness of possible deleterious effects of the chemicals, biological controls of plants pathogen have received considerable attention. ${ }^{5}$ The management of these nematodeparasites has little chance of success and is uneconomical because they live in the soil and feed on the internal plant tissues. Preventing the introduction of nematodes with planting material, seeds, or soil, using rotation and mixed cropping with the poor host, using nematode resistant varieties or rootstocks, and lowering nematode populations through nematicides are some of the most frequently used strategies. ${ }^{6}$ Until recently, methyl bromide was widely used to manage nematodes and other soil-borne pathogens in high-value horticultural crops. However, concerns on its impact on environment necessitate the ban or revoke of this methyl bromide in 2005 for its gas emission and global warming. Although nematicides are effective in nematode management, it discourages users because of their high costs, nonavailability at the time of need, the hazards they pose on human as well as on non-target organisms. ${ }^{7}$ Other options for the management of root-knot nematodes become imperative and there is an increasing interest in non-chemical nematode management strategies. ${ }^{8}$ Extract from certain plants is used to control certain nematode because environmental consideration and costs of nematicides dictate that other methods of control may be investigated, on alternative method is the use of antagonistic plants in rotation with or inter planted with crop plants. Certain medicinal plant extracts and their constituent were experimentally used for such aim. ${ }^{9-11}$ The current study was designed to evaluate the potential beneficial effects of some plant extracts such as lantana (Lantana camara), neem (Azadirachta indica), moringa (Moringaoleifera), and liquorices (Glycyrrhiza glabra) on controlling the root-knot nematode (Meloidogyne spp.) through their toxic effects on egg hatchability.

\section{Material and methods}

\section{Plant material used in the experiment}

As shown in (Table 1), plant materials of Moringaoleifera and neem were collected from mature plants grown at Demo Experimental Farm of Faculty of Agriculture, Fayoum University, and Fayoum, Egypt. In addition, Lantana camara leaves were collected from gardens of Faculty of Agriculture, Fayoum University, and Fayoum, Egypt. However, liquorice roots were collected from Anonymous fields located in Abshwai district, Fayoum Governorate, Egypt. 
Table I Information about the four plant species used in the present study

\begin{tabular}{lllll}
\hline English Name & Scientific Name & Family & Plant part used & Reference of previous use \\
\hline Lantana & Lantana camara & Verbenaceae & Leaves & Tayeet al.., ${ }^{40}$ \\
Neem & Azadirachtaindica & Meliaceae & Leaves & Tayeet al.., \\
Moringa & Moringaoleifera & Moringaceae & Leaves & Sowleyet al.., ${ }^{39}$ \\
Liquorice & Glycyrrhizaglabra & Fabaceae & Roots & Sardariet al., ${ }^{38}$ \\
\hline
\end{tabular}

\section{Preparation of plant extracts}

Plant leaves were plucked from their branches and spread on polythene sheets on benches in the laboratory for ten days to air dry. The dried materials were ground to fine particles using a blender. An amount of $400 \mathrm{ml}$ ethanol (95\%) (L. camara and G. glabra) and Petroleum Ether (A. indicaand M. oleifera) were added to $100 \mathrm{~g}$ of ground plant material and shaken on a rotary in a shaker at $120 \mathrm{rpm}$ for 24 hours. The solution was filtered through muslin cloths then through Whatman No. 1 filter paper and the material was vacuumed in a rotary evaporator at $40^{\circ} \mathrm{C}$ to obtain organic crude extracts (solvent is eliminated). ${ }^{12}$ Extracts were used at 4000, 2000, 1000 and 500ppm concentration that obtained by the dilution with distilled water.

\section{Extraction of nematode eggs}

Eggs were obtained from a culture of nematode infected roots of tomato, root pieces containing egg masses were cut into small pieces and placed in a container of $500 \mathrm{ml}$ capacity with $200 \mathrm{ml}$ of $0.5 \%$ Clorox (sodium hypochlorite, $\mathrm{NaOCI}$ ) solution shaken vigorously by hand for 4 min. ${ }^{13}$ This was done in order to digest the gelatinous matrix encasing the eggs. The solution was then poured through two nested sieves, 200 - mesh $(75 \mu \mathrm{m})$ and $500 \mathrm{mesh}(25 \mu \mathrm{m})$. Eggs in the $500 \mathrm{mesh}$ sieve were washed free of $\mathrm{NaOCI}$ solution with a slow stream of cold tap water into a container previously marked to contain $1 \mathrm{~L}$. The cut roots in the original container were washed twice with water to obtain additional eggs. The collected eggs were topped with water to obtain the egg-water suspension for in vitro studies.

\section{Counting of root-knot nematodes eggs}

Number of eggs in aqueous suspension was determined by using a stereo microscope. One milliliters of the egg-water suspension was pipette after bubbling air through the suspension for homogeneity and dispensed into a counting tray. Counting was done two times and the mean number of eggs $/ \mathrm{ml}$ estimated.

\section{Hatchability test}

Eggs were collected by the method of Hussey and Barker. ${ }^{13} \mathrm{~A}$ suspension of eggs in water was prepared. $1 \mathrm{ml}$ of egg suspension
$(100 \pm 10$ eggs $/ \mathrm{ml})$ and $5 \mathrm{ml}$ of leaf or root extract was transferred in Petri dishes and kept at room temperature. Each treatment was 3-time replicated. The Petri dishes containing $1 \mathrm{ml}$ egg suspension and 5 $\mathrm{ml}$ water served as control. After 24, 48, 72 hours of exposure, the number of hatching eggs was counted under an inverted microscope.

\section{Gas chromatography-mass spectrometry (GC/MS) analysis}

The GC column was a $30 \mathrm{~m}(0.25 \mathrm{~mm}$ i.d., film thickness $0.25 \mu \mathrm{m})$ HP-5MS (5\%diphenyl) dimethylpolysiloxane capillary column. The GC conditions were as follows: injector temperature, $240^{\circ} \mathrm{C}$; column temperature, isothermal at $50^{\circ} \mathrm{C}$ for $2 \mathrm{~min}$, then programmed to $280^{\circ} \mathrm{C}$ at $6^{\circ} \mathrm{C} / \mathrm{min}$ and held at this temperature for $2 \mathrm{~min}$; ion source temperature, $200^{\circ} \mathrm{C}$; detector temperature, $300^{\circ} \mathrm{C}$. Helium was used as the carrier gas at the rate of $1 \mathrm{ml} / \mathrm{min}$. The effluent of the GC column was introduced directly into the ion source of the MS. Spectra were obtained in the EI mode with $70 \mathrm{eV}$ ionization energy. The sector mass analyzer was set to scan from 40 to $400 \mathrm{amu}$ for $5 \mathrm{~s}$. These data were obtained from environmental and food pollutants laboratory at Faculty of Agriculture, Fayoum University.

\section{Results}

\section{Effect of exposure time and inhibition concentration (IC)}

Regarding the effect of some plant extracts on egg hatching of root-knot nematode after $72 \mathrm{~h}$, data in (Table 2) and (Figure1) (Figure2) show that toxicity of extract $\mathrm{IC}_{50}$ (Inhibition Concentration, $50 \%), \mathrm{IC}_{90}$ and slope value was calculated. It shows that neem extract is highly effective against egg hatching being the $\mathrm{IC}_{50}$ scored $202.55 \mathrm{ppm}$ followed by moringa extract $\mathrm{IC}_{50}$ conferred $497.55 \mathrm{ppm}$, while the least effective extract against egg hatching was liquorices extract $\mathrm{IC}_{50}$ granted $1479.15 \mathrm{ppm}$. Consequently, neem extract caused $64,76,84$ and $89 \%$ inhibition of egg hatching on root-knot nematode at the concentrations of 500,1000, 2000 and 4000ppm, respectively. In contrast, the liquorices extract at the concentrations of 500, 1000, 2000 and $4000 \mathrm{ppm}$ caused the inhibition \% of egg hatching of 15,44 , 63 and $74 \%$, respectively at $72 \mathrm{~h}$.

Table 2 Effect of some plant extracts on egg hatching (\%) of root-knot nematode (Meloidogyne spp.) after 72 hours exposure to the extracts.

\begin{tabular}{|c|c|c|c|c|c|c|c|c|c|}
\hline \multirow[t]{2}{*}{ Extract } & \multicolumn{4}{|c|}{ Concentration(ppm) } & \multirow[t]{2}{*}{ IC50(ppm) } & \multicolumn{2}{|c|}{ 95\% Confidence limits } & \multirow[t]{2}{*}{ IC90(ppm) } & \multirow[t]{2}{*}{ Slope \pm SE } \\
\hline & 500 & 1000 & 2000 & 4000 & & Lower & Upper & & \\
\hline Neem & $64 *$ & 76 & 84 & 89 & 202.6 & 46.3 & 374.7 & 4183.2 & $0.97 \pm 0.22$ \\
\hline Moringa & 49 & 66 & 77 & 86 & 497.6 & 268.3 & 686.2 & 5600.5 & $1.22 \pm 0.21$ \\
\hline Lantana & 33 & 55 & 70 & 79 & 920.8 & 693.5 & 1145.8 & 7741.2 & $1.39 \pm 0.20$ \\
\hline Liquorice & 15 & 44 & 63 & 74 & 1479.2 & 651.1 & 3547.9 & 7621.5 & $1.80 \pm 0.21$ \\
\hline
\end{tabular}

*Inhibition of egg hatchability (\%) 


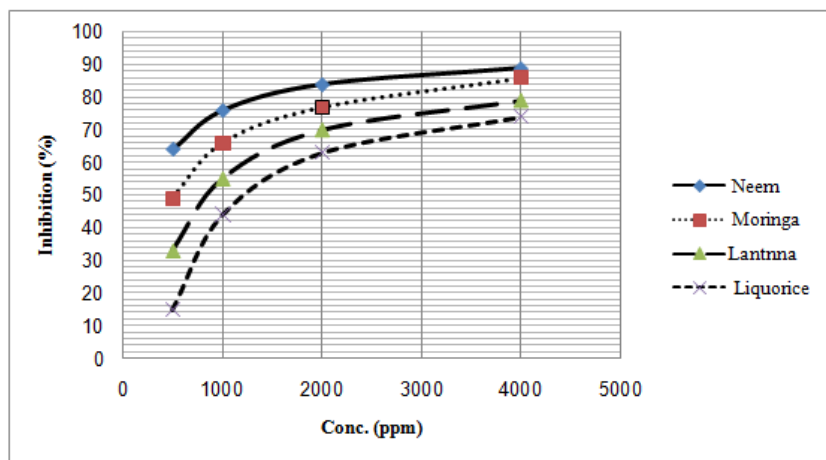

Figure I Effect of some plant extracts on egg hatching of root-knot nematode (Meloidogyne spp.) after 72 hours.

\section{Effect of plant extract, concentration and exposure time}

The mean performance of plant extract and the effect of the extract concentration and exposure time to extract on egg hatching of root-knot nematode are shown data in (Table 3). Data show that the egg hatching $(\%)$ was recorded the highest value with the

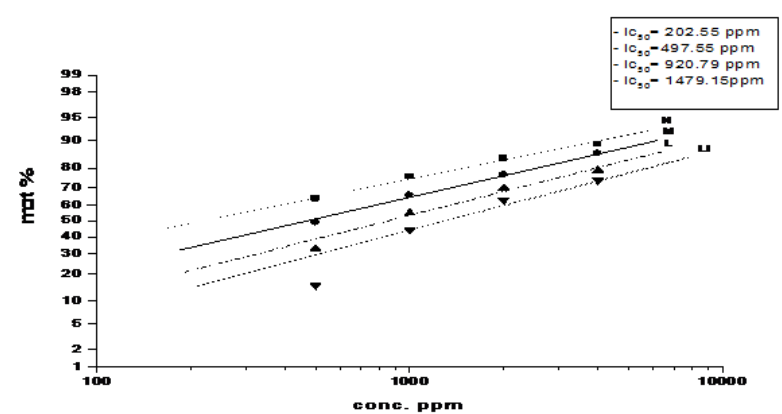

Figure 2 Effect of some plant extracts on egg hatching of root-knot nematode (Meloidogyne spp.) after 72 hours.

extract of Glycyrrhiza glabra followed by Lantana camara extract, then Moringaoleifera extract, and the lowest value was recorded with the extract of Azadirachta indica. The egg hatching (\%) was progressively reduced with increasing the extract concentration from 500 to $4000 \mathrm{ppm}$. In contrast, the egg hatching (\%) was progressively increased with increasing the exposure time from 24 to $72 \mathrm{~h}$.

Table 3 Mean performance $( \pm$ SE) of plant extract, concentration and time of egg hatching on Meloidogyne spp.

\begin{tabular}{lllllc}
\hline Plant & Means(\%) $\pm S E$ & Conc.(ppm) & Means(\%) $\pm S E$ & Time (h) & Means(\%) \pm SE \\
\hline Azadirachtaindica & $32.1 \pm 2.9 \mathrm{~d}$ & 0 & $80.8 \pm 2.1 \mathrm{a}$ & 24 & $34.3 \pm 1.7 \mathrm{c}$ \\
Moringaoleifera & $38.5 \pm 2.7 \mathrm{c}$ & 500 & $48.3 \pm 2.2 \mathrm{~b}$ & 48 & $44.7 \pm 2.5 \mathrm{~b}$ \\
Lantana camara & $46.0 \pm 2.6 \mathrm{~b}$ & 1000 & $36.3 \pm 1.4 \mathrm{c}$ & 72 & $48.7 \pm 2.9 \mathrm{a}$ \\
Glycyrrhizaglabra & $53.6 \pm 2.7 \mathrm{a}$ & 2000 & $24 . \pm 1.0 \mathrm{~d}$ & - & - \\
- & - & 4000 & $16.5 \pm 0.7 \mathrm{e}$ & - & - \\
\hline
\end{tabular}

\section{Interactive effect of plant extract and its concentration}

The interactive effect of plant extract and its concentration on egg hatching of root-knot nematode is presented in (Table 4) and (Figure 3). Neem extract significantly decreased egg hatching of root-knot nematode. The percentages of reductions of egg hatching were $59.01,73.03,81.83$ and $87.34 \%$ by application of neem extract (Azadirachtaindica) at the concentrations of 500, 1000, 2000 and $4000 \mathrm{ppm}$, respectively compared to the control (water). Egg hatching of root-knot nematode was significantly decreased egg hatching by moringa extract (Moringaoleifera) application. The percentages of reductions of egg hatching were $42.36,61.48,74.27$ and $83.77 \%$ of the moringa extract at the concentrations of 500,1000, 2000 and 4000ppm, respectively compared to the control. Lantana extract (Lantana camara) significantly decreased egg hatching of root-knot nematode. The percentages of reductions of egg hatching were 23.38, 49.24, 66.16 and $76.47 \%$ by application of lantana extract at the concentrations of $500,1000,2000$ and 4000ppm, respectively compared to the control. Egg hatching of root-knot nematode was significantly decreased egg hatching by liquorices extract (Glycyrrhizaglabra) application. The percentages of reductions of egg hatching were 3.71, 36.45, 57.36 and $70.69 \%$ by application of liquorices extract at the concentrations of

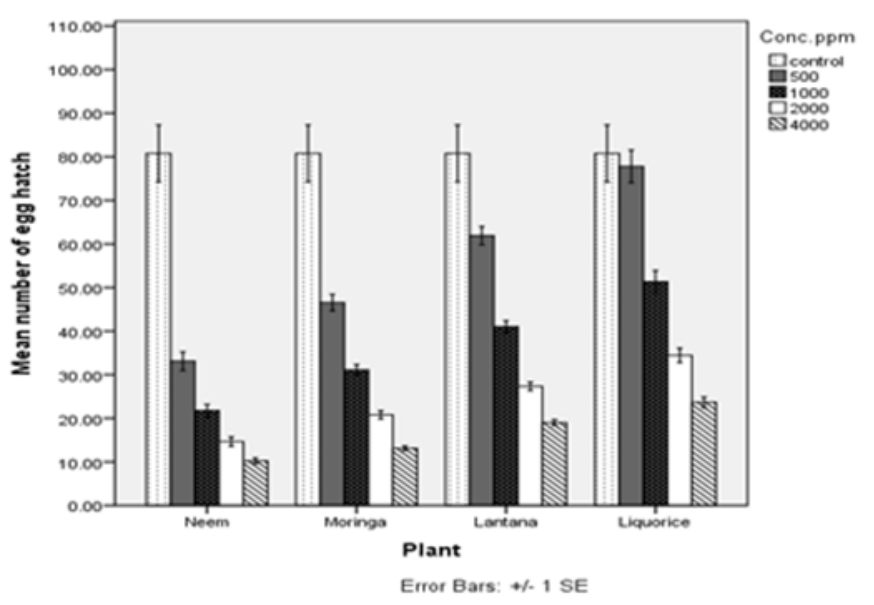

Figure 3 Mean performance of interaction between plant extract and the concentration of egg hatching on Meloidogynes pp. 
Table 4 Mean performance $( \pm \mathrm{SE})$ of interaction between plant extract and concentration on egg hatching of Meloidogyne spp.

\begin{tabular}{|c|c|c|}
\hline Plant & Concentration(ppm) & Means(\%) \pm SE \\
\hline \multirow[t]{5}{*}{ Azadirachtaindica } & 0 & $80.8^{*} \pm 4.4 \mathrm{a}$ \\
\hline & 500 & $33.1 \pm 1.3 f$ \\
\hline & 1000 & $21.8 \pm 0.9 \mathrm{hi}$ \\
\hline & 2000 & $14.7 \pm 0.6 \mathrm{j}$ \\
\hline & 4000 & $10.2 \pm 0.4 \mathrm{k}$ \\
\hline \multirow[t]{5}{*}{ Moringaoleifera } & 0 & $80.8 \pm 4.4 a$ \\
\hline & 500 & $46.6 \pm 1.3 d$ \\
\hline & 1000 & $3 I .1 \pm 0.8 \mathrm{f}$ \\
\hline & 2000 & $20.8 \pm 0.7 \mathrm{hi}$ \\
\hline & 4000 & $13.1 \pm 0.4 \mathrm{jk}$ \\
\hline \multirow[t]{5}{*}{ Lantana camara } & 0 & $80.8 \pm 4.4 a$ \\
\hline & 500 & $61.9 \pm 1.4 b$ \\
\hline & 1000 & $41.0 \pm 1.0 \mathrm{e}$ \\
\hline & 2000 & $27.3 \pm 0.7 \mathrm{~g}$ \\
\hline & 4000 & $19.0 \pm 0.5 i$ \\
\hline \multirow[t]{5}{*}{ Glycyrrhizaglabra } & 0 & $80.8 \pm 4.4 a$ \\
\hline & 500 & $77.8 \pm 2.7 a$ \\
\hline & 1000 & $51.3 \pm 1.9 c$ \\
\hline & 2000 & $34.4 \pm 1.2 f$ \\
\hline & 4000 & $23.7 \pm 0.9 h$ \\
\hline
\end{tabular}

*Inhibition of egg hatchability (\%)

\section{Interactive effect of plant extract and exposure time:}

(Table 5) (Figure 4) illustrate the interactive effect of plant extract and exposure time on egg hatching of root-knot nematode, the most effective extract at decreasing the egg hatching is Azadirachta indica followed by Moringaoleifera, and the lowest effective extract at inhibiting the egg hatching is Glycyrrhiza glabra.

Table 5 Mean performance and S.E. of interaction between plant extract and time of egg hatching on Meloidogyne spp.

\begin{tabular}{lll}
\hline Plant & Time (h) & Means(\%) \pm SE \\
\hline Azadirachtaindica & 24 & $25.1 * \pm 3.3 \mathrm{j}$ \\
& 48 & $33.9 \pm 5.2 \mathrm{~h}$ \\
Moringaoleifera & 72 & $37.3 \pm 6.1 \mathrm{~g}$ \\
& 24 & $30.7 \pm 3.3 \mathrm{i}$ \\
& 48 & $40.5 \pm 4.9 \mathrm{f}$ \\
Lantana camara & 72 & $44.3 \pm 5.7 \mathrm{e}$ \\
& 24 & $37.3 \pm 3.0 \mathrm{~g}$ \\
& 48 & $48.2 \pm 4.6 \mathrm{~d}$ \\
Glycyrrhizaglabra & 72 & $52.5 \pm 5.3 \mathrm{c}$ \\
& 24 & $43.9 \pm 3.3 \mathrm{e}$ \\
& 48 & $56.2 \pm 4.6 \mathrm{~b}$ \\
& 72 & $60.7 \pm 5.3 \mathrm{a}$ \\
\hline
\end{tabular}

*Inhibition of egg hatchability (\%)

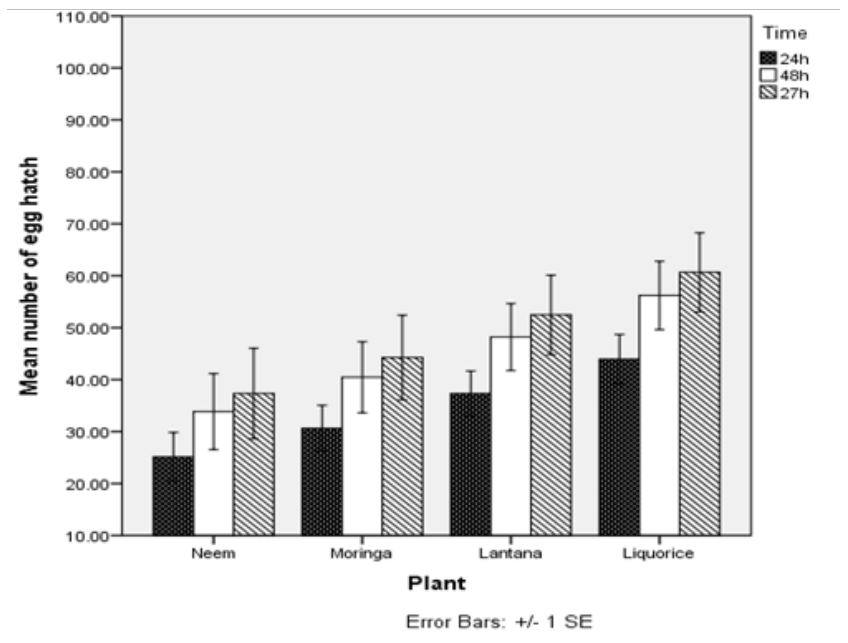

Figure 4 Mean performance of interaction between plant extract and time of egg hatching on Meloidogyne spp.

\section{Interactive effect of plant extract, concentration and exposure time:}

(Table 6) (Figure 5) reveal the interactive effect of plant extract, concentration and exposure time on nematode egg hatching Under the application of plant extract concentration for different periods, the lowest effective plant extract concentration was $500 \mathrm{ppm}$, which gave the least inhibition, followed by $1000 \mathrm{ppm}$. The highest effective extract concentration was $4000 \mathrm{ppm}$, conferring the lowest egg hatching.

Table 6 Mean performance $( \pm$ SE) of interaction between concentration and time of egg hatching on Meloidogyne spp.

\begin{tabular}{|c|c|c|}
\hline Concentration(ppm) & Time(h) & Means(\%) $\pm S E$ \\
\hline \multirow[t]{3}{*}{0} & 24 & $56.7 \pm 0.9 d$ \\
\hline & 48 & $85.7 \pm 0.7 b$ \\
\hline & 72 & $100.0 \pm 0.0 \mathrm{a}$ \\
\hline \multirow[t]{3}{*}{500} & 24 & $47.7 \pm 3.2 \mathrm{e}$ \\
\hline & 48 & $57.2 \pm 3.7 \mathrm{~cd}$ \\
\hline & 72 & $59.7 \pm 3.9 c$ \\
\hline \multirow[t]{3}{*}{1000} & 24 & $31.6 \pm 2.1 \mathrm{gg}$ \\
\hline & 48 & $37.9 \pm 2.5 f$ \\
\hline & 72 & $39.4 \pm 2.6 f$ \\
\hline \multirow[t]{3}{*}{2000} & 24 & $2 I . I \pm I .5 i$ \\
\hline & 48 & $25.4 \pm 1.7 \mathrm{~h}$ \\
\hline & 72 & $26.4 \pm 1.8 \mathrm{~h}$ \\
\hline \multirow[t]{3}{*}{4000} & 24 & $14.3 \pm 1.0 \mathrm{k}$ \\
\hline & 48 & $17.3 \pm 1.2 \mathrm{jk}$ \\
\hline & 72 & $17.9 \pm 1.2 \mathrm{j}$ \\
\hline
\end{tabular}




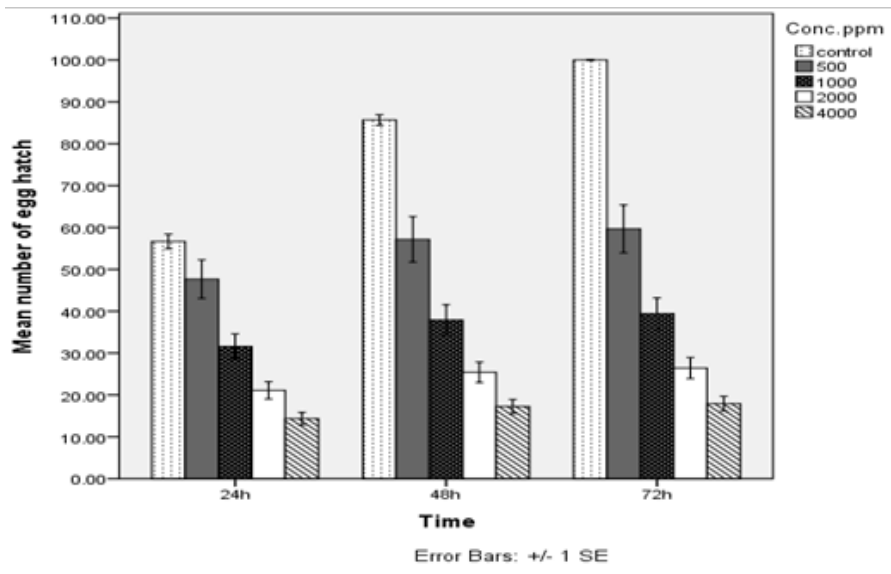

Figure 5 Mean performance of interaction between concentration and time of egg hatching on Meloidogyne spp.

\section{Effect of plant extract at different periods:}

(Table 7) (Figures 6-8) show the effect of plant extract on hatching of root-knot nematode at different periods. The four plants; neem, moringa, lantana and liquorices were tested at different concentrations (500, 1000, 2000 and 4000ppm) for egg hatching of root-knot nematode. The results show a gradual decrease in egg hatching with increasing the concentration of each extract. The increase in exposure period and an increase of the concentration also decrease of egg hatching. After $24 \mathrm{~h}$ application of the extracts on root-knot nematode eggs, the mean egg hatching ranged from 8.67 to $67.67 \%$. The highest egg hatching was observed in the G. glabra, whilst the lowest was observed with the $A$. indica. At $48 \mathrm{~h}$, mean egg hatching was ranged between 11.00 and $85.67 \%$. The highest egg hatching was found in the control, whilst the least hatch was in the $A$. indica extract. In addition, at $72 \mathrm{~h}$ mean egg hatching was ranged between 11.00 to $100 \%$. The highest egg hatching was observed in the control treatment, whilst the lowest hatching was found out in the $A$. indica extract. The most effective plant extract inhibition of egg hatching was $A$. indica extract at the concentration of $4000 \mathrm{ppm}$, which conferred the lowest egg hatching.

Table 7 Effect of some plant extracts on hatching of Meloidogynes pp. egg at different periods.

\begin{tabular}{|c|c|c|c|c|}
\hline \multirow[t]{2}{*}{ Treatment } & \multirow[t]{2}{*}{ Conc.(ppm) } & \multicolumn{3}{|c|}{ Mean number of egg hatching (\%) } \\
\hline & & $24 \mathrm{~h}$ & $48 \mathrm{~h}$ & $72 \mathrm{~h}$ \\
\hline \multirow[t]{4}{*}{ Azadirachtaindica } & 500 & $28.7 \pm 1.6 n \_9$ & 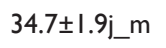 & $36.0 \pm 2.1 \mathrm{jk}$ \\
\hline & 1000 & $19.0 \pm 1.1 \mathrm{t} \_z$ & $22.7 \pm 1.4 r \_u$ & $23.7 \pm 1.4 q \_u$ \\
\hline & 2000 & $12.7 \pm 1.0 \mathrm{a} \_c$ & $15.3 \pm 1.0 x \_b$ & $16.0 \pm 1.1 \mathrm{w} \_b$ \\
\hline & 4000 & $8.7 \pm 0.5 c$ & $11.0 \pm 0.7 \mathrm{bc}$ & $11.0 \pm 0.7 \mathrm{bc}$ \\
\hline \multirow[t]{4}{*}{ Moringaoleifera } & 500 & $40.0 \pm 1.1$ hij & $48.7 \pm \mathrm{I} .6 \mathrm{fg}$ & $50.7 \pm 1.6 \mathrm{ef}$ \\
\hline & 1000 & $27.0 \pm 0.7 \circ \_r$ & $32.7 \pm 0.9 \mathrm{k} \_0$ & $33.7 \pm 0.9 k \_n$ \\
\hline & 2000 & $18.0 \pm 0.7 u \_a$ & $21.7 \pm 0.9 r \_w$ & $22.7 \pm 0.9 r \_u$ \\
\hline & 4000 & $11.3 \pm 0.5 \mathrm{bc}$ & $13.7 \pm 0.2 z \_c$ & $14.3 \pm 0.5 y \_c$ \\
\hline \multirow[t]{4}{*}{ Lantana camara } & 500 & $54.0 \pm 0.5 \mathrm{~d} \_f$ & $64.3 \pm 0.7 \mathrm{c}$ & $67.3 \pm 0.7 c$ \\
\hline & 1000 & $35.7 \pm 0.3 \mathrm{j} \_\mathrm{I}$ & $42.7 \pm 0.3 \mathrm{hi}$ & $44.7 \pm 0.3 \mathrm{gh}$ \\
\hline & 2000 & $23.7 \pm 0.3 q \_u$ & $28.7 \pm 0.3 n \_9$ & $29.3 \pm 0.3 \mathrm{~m} \_\mathrm{P}$ \\
\hline & 4000 & $16.7 \pm 0.3 w \_b$ & $19.7 \pm 0.3 \mathrm{t} \_y$ & $20.7 \pm 0.3 s \_x$ \\
\hline \multirow[t]{4}{*}{ Glycyrrhizaglabra } & 500 & $67.7 \pm 3.4 \mathrm{c}$ & $81.0 \pm 3.8 \mathrm{~b}$ & $84.7 \pm 4.1 \mathrm{~b}$ \\
\hline & 1000 & $44.7 \pm 2.5 \mathrm{gh}$ & $53.7 \pm 2.9 d \_f$ & $55.7 \pm 2.9 \mathrm{de}$ \\
\hline & 2000 & $30.0 \pm 1.61 \_p$ & $36.0 \pm 1.6 \mathrm{jk}$ & $37.3 \pm 1.8 \mathrm{i} \_\mathrm{k}$ \\
\hline & 4000 & $20.7 \pm 1.0 s \_x$ & $24.7 \pm 1.4 \mathrm{P} \_\mathrm{t}$ & $25.7 \pm 1.4 \mathrm{p} \_s$ \\
\hline Control & 0 & $56.7 \pm 2.2 \mathrm{~d}$ & $85.7 \pm 1.5 b$ & $100.0 \pm 0.0 \mathrm{a}$ \\
\hline
\end{tabular}

Data are means \pm S.E. different lower or upper letters in a column indicate significant differences between the treatments at $P \leq 0.05$. 


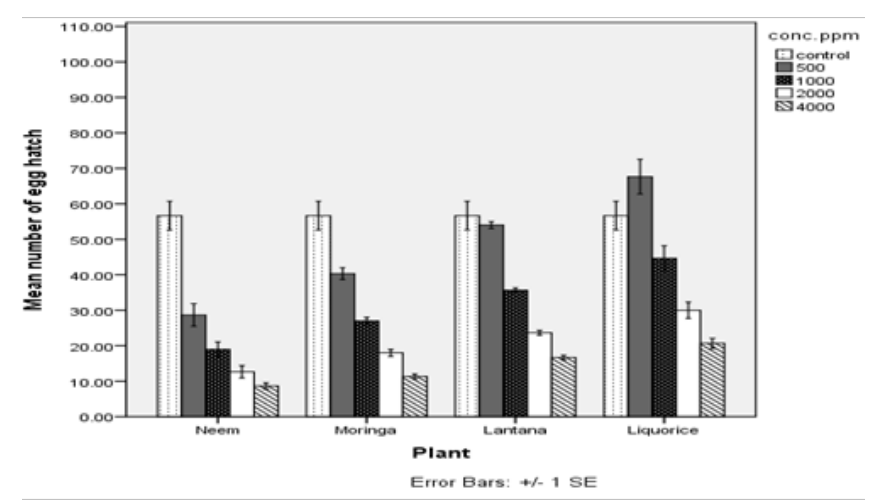

Figure 6 Effect of some plant extract on hatching of Meloidogyne spp. egg at 24.

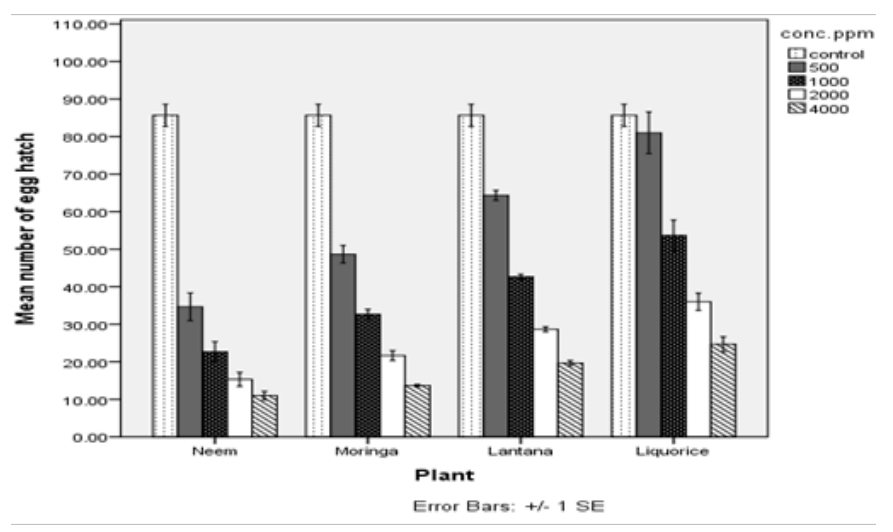

Figure 7 Effect of some plant extract on hatching of Meloidogynes pp. egg at $48 \mathrm{~h}$.

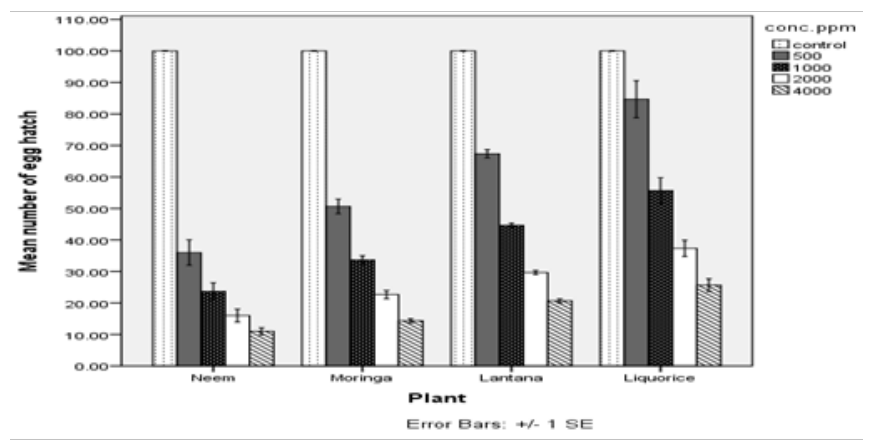

Figure 8 Effect of some plant extract on hatching of Meloidogyne spp. egg at $72 \mathrm{~h}$.

\section{Active chemical compounds of neem leaf extract}

As the most effective extract inhibiting nematode egg hatching, the GC/MS analysis (Figure 9) of the leaf extract of neem showed the following active chemical compounds: Hexane, 2, 4-dimethyl; Hexane, 2,2,5-trimethyl;Cyclohexane, 2,4-diethyl-1-methyl-; Methylbicyclo [4.2.0] octane; Methallylcyclohexane; Cyclohexane ethyl-; Heptane, 2,6-dimethyl; Cyclohexane, 1,2,4-trimethyl-, $(1 \alpha, 2 \beta, 4 \beta)-;$ Trans-1,2-Diethyl cyclopentane; Octane, 4- methyl-; Heptane, 2,3-dimethyl-; Benzene, 1,3-dimethyl-; Cyclohexane, 1,1,2-trimethyl-; Cyclopentane, 1-methyl-2-propyh-; 1-Ethyl-4- methylcyclohexane; p-Xylene; Nonane; Cyclohexane, 1-ethyl-4methyl-, cis-; Benzene (1-methylethyl)-; Cyclohexane, propyl-; Octane, 2,6-dimethyl-; Benzene, propyl-; Heptane, 3-ethyl-2methyl-; Benzene, 1-ethyl-2- methyl-; Benzene, 1,2,3-trimethyl-; Decane; Decane, 4-methyl-; Decane, 2-methyl, Undecane; Undecane, 2-methyl-; Dodecane; -; o-Xylene; Mesitylene; and Naphthalene, decahydro-, trans-.

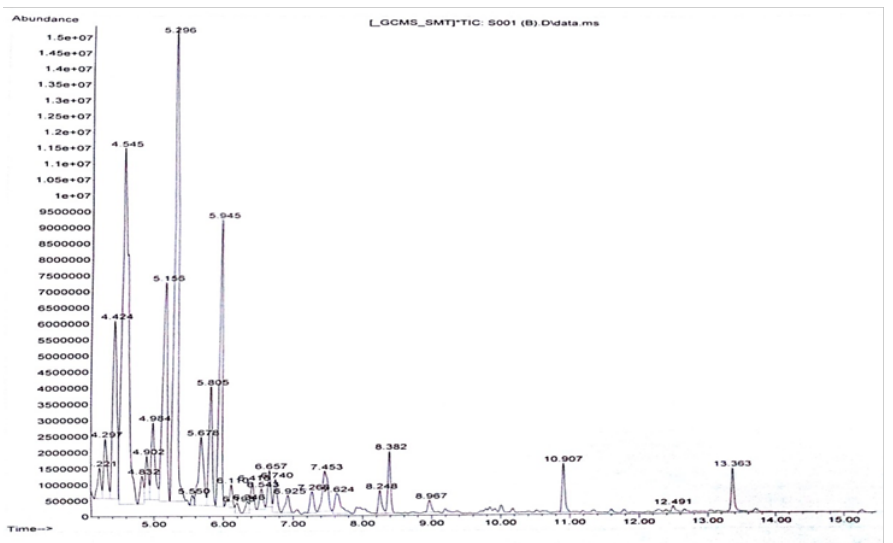

Figure 9 Chromatogram obtained from the GC-MS with the extract of Azadirachta indica leaves.

\section{Discussion}

The recent approach in nematode control is direct method towards the possibility of reducing populations of plant-parasitic nematodes in soil by using natural substances extracted from some plants. Such methods don't lead to the disturbance of the biological balance of nature. Utilization of antagonistic plants or their byproducts is of common use all-over the world for avoiding hazards of the traditional chemical nematicides. The use of certain plant extracts for controlling plant-parasitic nematodes has been increased in the recent years. ${ }^{14-17}$ The plant extracts which tested in this study found in most cases to have an antagonistic action and a higher nematicidal activity against root-knot nematode. So, they undoubtedly contain natural nematotoxic constituents that able to inhibit the nematode egg hatching. In a study conducted by Hussaini et al., ${ }^{18}$ it has been reported that leaf extracts of 11 plant species inhibited egg hatching and caused 90\% larval mortality in M. incognita, M. javanica, and M. arenaria. Our results are in parallel line with the results of Hussaini et al., ${ }^{18}$ In addition, results of the current study are in agreement with the results of Nandal \& Bhatti ${ }^{19}$ who have reported that some of the plant extracts showed significant nematicidal properties. According to Khan, ${ }^{20}$ many wild and cultivated medicinal plants have been shown to possess nematicidal properties against several plant-parasitic nematodes. The results of the study showed that neem extract had a toxic effect on the root-knot nematode in vitro by inhibiting the egg hatching at different concentrations of the extract. It was also observed that inhibition of egg hatching increased with increasing the concentration of the extract with the highest score that was recorded with the extract concentration of $4000 \mathrm{ppm}$. This observation agrees with the findings of Adegbite and Adesiyan ${ }^{21}$ working with root extracts of Azadirachtaindica, Chromolaenaodorata, Ricinuscommunis and Jatrophacurcas and recorded the gradual increase in inhibition of egg hatching with increasing the concentration of the extract. A similar 
finding was reported by Ameer-Zareen et al., ${ }^{22}$ on root-knot nematode eggs in vitro when they have used the aqueous extract of ginger (Zingiberofficinale). This study also agrees with the results of Barker ${ }^{23}$ that nematode egg hatching was influenced by the exudates from its environment. In addition, egg hatching inhibition was increased with increase in exposure time, and this result also agrees with the results of Joymatti et al., ${ }^{24}$ The inhibitory effect of plant extracts on egg hatching of nematode according to Adegbite \& Adesiyan, ${ }^{21}$ might be due to the properties of the chemical compounds present in the extract that possess ovicidal properties. It was also suggested that botanicals with nematicidal properties affect the embryonic development or kill the eggs. Presumably, these properties found to increase with an increase in time, hence, the inhibition of egg hatching tend to increase with increasing the exposure period to the extract. These active chemicals either affect the embryonic development or kill the eggs or even dissolve the egg masses. It has been reported by Adegbite, ${ }^{25}$ Goswami et al., ${ }^{26}$ and Hackney et al., ${ }^{27}$ that extracts (i.e., Siam weed; Chromolaenaodorata L., Neem; Azadirachtaindica A. Jass, Castor bean; Ricinuscommunis L., and Lemon grass; Cymbopogoncitratrus DC.) that contained alkaloids, flavonoids, saponins, amides including benzamide and ketenes in a single form or in a combination inhibited nematode egg hatching. From the results of the present study, it has been found that neem extract was recorded the best results regarding inhibition of egg hatching compared to moringa, lantana, and liquorices extracts. Therefore, neem extract was exposed to GC/MS analysis to find out the active chemical compounds (Figure 9) that caused the toxicity effect on nematodes. The active chemical compounds found in this outbalanced extract and identified it as a best effective extract in inhibition of egg hatching are alkaloids, flavonoids, saponins, amides including benzamide and ketones, and others as follows: Hexane, 2, 4-dimethyl; Hexane, 2,2,5-trimethyl-;Cyclohexane, 2,4-diethyl1-methyl-; Methylbicyclo [4.2.0] octane; Methallylcyclohexane; Cyclohexane ethyl-; Heptane, 2,6-dimethyl; Cyclohexane, 1,2,4-trimethyl-, $\quad(1 \alpha, 2 \beta, 4 \beta)-; \quad$ Trans-1,2-Diethyl cyclopentane; Octane, 4- methyl-; Heptane, 2,3-dimethyl-; Benzene, 1,3-dimethyl-; Cyclohexane, 1,1,2-trimethyl-; Cyclopentane, 1-methyl-2-propyh-; 1-Ethyl-4-methylcyclohexane; p-Xylene; Nonane; Cyclohexane, 1-ethyl-4-methyl-, cis-; Benzene (1-methylethyl)-; Cyclohexane, propyl-; Octane, 2,6-dimethyl-; Benzene, propyl-; Heptane, 3-ethyl2-methyl-; Benzene, 1-ethyl-2- methyl-; Benzene, 1,2,3-trimethyl-; Decane; Decane, 4-methyl-; Decane, 2-methyl, Undecane; Undecane, 2-methyl-; Dodecane; -; o-Xylene; Mesitylene; and Naphthalene, decahydro-, trans-. Figure 9 expresses the presence of bioactive compounds which had been detected in petroleum ether extract of Azadirachtaindica during GC-MS analysis. According to Sharma et al., ${ }^{28}$ 4-hydroxy-4-methyl-2-pentanone, hexadecenoic acid (palmitoleic acid), hexadecanoic acid (palmitic acid), pentadecanoic acid, octadecene, diethylhexyl phthalate, cyclohexadiene-1-one and 1,2-benzenedicarboxylic acid were identified as main compounds from the rhizobacteria Pseudomonas jessenii strain R62 and Pseudomonas synxantha strain R81 extracts that had toxic effects on against root-knot nematode, Meloidogyne incognita second stage juveniles (J2). Many of these active chemical components were discovered in the extract of our study and showed toxic effects on egg hatching of Meloidogyne incognita. Our study is also in accordance, partially, with the others ${ }^{29-30}$ where they reported that the ethyl acetate extract caused 64\% inactivity in Meloidogynejavanica within $24 \mathrm{~h}$ ' exposure and assumed that the active compound might be of proteinaceous or glycoproteinaceous in nature. Likewise, Padgham
\& Sikora $^{31}$ reported that Bacillus megaterium cause repellence of M. graminicola from rice roots. Adam et al., ${ }^{32}$ reported combined effect of bacteria produced systemic resistance in tomato due to the presence of nematicidal compounds. In GC-MS analysis large numbers of compounds were identified; some of these compounds are already known to be bioactive. Dibutyl phthalate, ${ }^{33}$ heneicosane ${ }^{34}$ and pentadecanoic acid ${ }^{35}$ are reported as antimicrobial in nature. Hexadecenoic acid and hexadecanoic acid identified in the bioactive extracts were found to be active against nematode. ${ }^{33} 4$-Hydroxy4methyl-2-pentanone has been reported to possess antibiotic, ${ }^{36}$ while 2,4- di-ter-butyl-phenol showed antioxidant activity. ${ }^{37-40}$ Many of the compounds found in the extract of Azadirachtaindica also remained unidentified in GC-MS analysis due to similar fragmentation pattern of many compounds with different retention times. It has been concluded from the results of the present study that the leaf extract of Azadirachtaindica has the ability to inhibit the egg hatchability of root-knot nematode. Thus, this finding is important in the identification and development of alternative strategies in controlling the root-knot nematodes. There is, however, further work is needed to identify some of these main compounds after purification. This study confirms the presence of nematicidal compounds in petroleum ether fractions of Azadirachtaindica, which were responsible for the prevention of egg hatching of root-knot nematodes at some concentrations, especially 4000ppm.

\section{Acknowledgements}

None.

\section{Conflict of interest}

The author declares there is no conflict of interest.

\section{References}

1. Perry RN. Understanding the survival strategies of nematodes. Animal Science Reviews.2011;99-102.

2. Ahmad F, Rather MA, Siddiqui MA. Nematicidal activities of leaf extract from Lantana camara L. against Meloidogyne incognita (Kofoid and White) Chitwood and its use to manage root infection of Solanummelongena L. Brazilian Archives of Biology and Technology.2010;53(3):543-548.

3. Davis EL, Hussey RS, Baum TJ. Getting to the roots of parasitism by nematodes. Trends Parasitol. 2004;20(3):134-142.

4. Elekcioglu IH, Ohnesorge B, Lung G. et al. Plant-parasitic nematodes in the Mediterranean region of Turkey. Nematologia Mediterranea. 1994;22(1):59-63.

5. Garima G, Singh A, Trivedi PC. Bacteria: A potential bioagent against root-knot nematode, Meloidogyne incognita. National Symposium on Recent Advances and Research Priorities in Indian Nematology; IARI, New Delhi. 2005;14-20.

6. Ploeg A. Biofumigation to manage plant-parasitic nematodes. In: Ciancio, et al. editors. Integrated Management and Biocontrol of Vegetable and Grain Crops Nematodes. Springer Vegetable and Grain Crops Nematodes, Netherlands. 2008:239-248.

7. Nagaraju N, Karemegam N, Kadalmani B. Eco-friendly management of root-knot nematode Meloidogyneincognita using organic amendments on tomato. International Journal of Research Pharmacological Science. 2010;1:530-532.

8. Kerry BR. An assessment of progress toward microbial control of plantparasitic nematode. J Nematol. 1990;22(4):621-631. 
9. Jeyaprakash K, Ayyanar M, Geetha KN, et al. Traditional uses of medicinal plants among the tribal people in Theni district (Western Ghats), South India. Asian Pacific Journal of Tropical Biomedicine. 2011;1(1):S20-25.

10. Kadam PV, Kavita NY, Ramesh SD, et al. Mimusopselengi: a review on ethnobotany,phytochemical andpharmacological profile. Journal of Pharmacognosy and Phytochemistry.2012:1(3):71-78.

11. Azhagumurugan C, Ranjan MK. Effect of leaf extract of nilkumil, (Gmelinaasiatica) against the root-knot nematode, (Meloidogyne incognita). Research Journal of Recent Sciences. 2014;3:264-266.

12. Brauer M, Devkota B. Control of Thaumatopoeapiyocampa (Den. \& Schiff) by extracts of Meliaazedarach L. (Meliaceae). Journal of Applied Entomology. 1990;110:128-135.

13. Hussey RS, Baker RR. A comparison of methods of collecting inocula of Meloidogyne spp. Including a new technique. Plant Disease Reporter.1973;57:1025-1028.

14. Pandey RC, Dwivedi BK. Comparative study of different plant extracts for their nematicidal potential. Current Nematology. 2000;11(1-2):39-43.

15. Dias CR, Schwan AV, Ezequiel DP, et al. Effect of aqueous extracts of some medicinal plants on the survival of Meloidogyne incognita juveniles. Nematologia Brasileira. 2000;24(2): 203-210.

16. Insunza V, Aballay E, Macaya J. In vitro nematicidal activity of aqueous plant extracts on Chilean populations of Xiphinema americanum sensulato. Nematropica. 2001;31(1):47-54.

17. Rakesh P, Alok K, Neetu K, et al. Nematicidal activity in flower of some medicinal and aromatic plants. Indian Journal of Nematology. 2001;31(1):96-98.

18. Hussaini SS, Rao RVVP, Pandu HK. Toxicity of water soluble leaf extracts against larvae and egg masses of threeMeloidogynespecies. Indian Journal of Nematology. 1996;26(1):23-31.

19. Nandal SN, Bhatti DS. Preliminaryscreening of some weeds shrubs for their nematicidal activity. Indian Journal of Nematology.1983;28(2):253-255.

20. Khan AF. Nematicidal potential of some naturally growing plants against Pratylenchus zeae. Revenue Nematology. 1990;13(4):463-465.

21. Adegbite AA, Adesiyan SO. Root extracts of plants to control root-knot nematode on edible soybean. World Journal of Agricultural Science. 2005;1(1):18-21.

22. Ameer-Zareen, Zaki JM, Javed N. Nematicidal activity of ginger and its effect on the efficacy Pasteuriapenetransfor the control of root-knot nematodes. Asian Journal of Plant Science. 2003;2(11):858-860.

23. Barker ADP. Novel approaches to potato cyst nematode control. In Abstracts Conference on Potato Production - Living with Pesticide Changes. New York. 2003.

24. Joymati L, Dhanachand C, Devi LS. Effect of plant extracts on $M$. incognita. Indian Journal of Nematology. 1998;28:225-230.

25. Adegbite AA. Comparative effects of carbofuran and water extract of chromolonaodorata on growth, yield and food component of rootknot nematodes infested soybean (Glycine max L. Merril) Ph.D. Diss., University of Ibadan, Ibadan, Nigeria. J Veg Sci. 2003;12:5-12.
26. Goswami BK, Vijayalakshmi V. Nematicidal properties of some indigenous plant materials against root-knot nematode Meloidogyne incognita on tomato. Indian Journal of Nematology. 1986;16(1):65-68.

27. Hackney RW, Dickerson OJ. Marigold, castor bean and Chrysanthemumas control ofMeloidogyne incognita and Pratylenchusalleni. J Nematol. 1975;7(1):84-90.

28. Sharma IP, Sharma AK, Prashad L, et al. Natural bacterial cell-free extracts with powerful nematicidal activity on root-knot nematode. Rhizosphere. 2018;5:67-70.

29. Siddiqui IA, Qureshi SA, Sultana V, et al. Biological control of root rotroot knot disease complex of tomato. Plant Soil. 2000;227(1-2):163-169.

30. Oliveira DF, Campos VP, Amaral DR, et al. Selection of rhizobacteria able to produce metabolitesactiveagainst Meloidogyne exigua. European Journal of Plant Pathology. 2007;119(4):477-479.

31. Padgham JL, Sikora RA. Biological control potential and modes of action of Bacillus megaterium against Meloidogyne graminicola on rice. Crop Prot. 2007;26(7):971-977.

32. Adam M, Heuer H, Hallmann J. Bacterial antagonists of fungal pathogens also control root-knot nematodes by induced systemic resistance of tomato plants. PLOS One. 2014;9(2):1-8.

33. Rajeswari G, Murugan M, Mohan VR. GC-MS analysis of bioactive components of Hugoniamystax L. (Linaceae). Res J Pharma Biol Chem Sci. 2012;3:301-308.

34. Boussaada O, Saidana D, Chriaa J, et al. Chemical composition and antimicrobial activity of volatile components of Scorzonera undulate. $J$ Essen Oil Res. 2008;20:1-5.

35. Yuan J, Raza W, Shen Q, et al. Antifungal activity of bacillus amyloliquefaciens NJN-6 volatile compounds against fusariumoxysporum f. sp. Cubense. Appl Environ Microbiol. 2012;78(16):5942-5944.

36. Okudoh VI, Wallis FM. Enhanced recovery and identification of a tryptamine related antibiotic produced by intrasporangium N8 from KwaZulu-Natal, South Africa. Trop J Pharma Res. 2012;11(5):729-737.

37. Choi SJ, Kim JK, Kim HK, et al. 2,4-Di-tert-butylphenol from sweet potato protects against oxidative stress in PC12 cells and in mice. $\mathrm{J} \mathrm{Med}$ Food. 2013;16(11):977-983.

38. Sardari AA, HojatJalili AA, Bahraminejad S, et al. Effect of plant extracts on the mortality of root-knot nematodes' J2, Meloidogyne javanica. Archives of Phyto pathology and Plant Protection. 2015;48(4):365-375.

39. Sowley ENK, Kankam F, Adomako J. Management of root-knot nematode (Meloidogyne spp.) on sweet pepper (Capsicum annuum L.) with moringa (Moringaoleifera Lam.) leaf powder. Archives of Phytopathology And Plant Protection. 2014;13:1531-1538.

40. TayeW,SakhujaPK, TeferaT.Root-knotnematode(Meloidogyneincognita) management using botanicals in tomato (Lycopersiconesculentum). Academia Journal of Agricultural Research. 2014;1(1):9-16. 